\title{
Aleksandra Reimann
}

\section{Muzyczny styl odbioru - muzyczny interpretant - literacka forma muzyczna}

\begin{abstract}
Reimann Aleksandra, Muzyczny styl odbioru - muzyczny interpretant - literacka forma muzyczna [Musical style of reception - a musical interpretant - musical form in literature]. „Przestrzenie Teorii" 17. Poznań 2012, Adam Mickiewicz University Press, pp. 139-161. ISBN 978-83-232-2449-5. ISSN 1644-6763.

The paper is concerned with reception strategies where interdisciplinary competencies are connected to musical expectations towards a text, which - i.a. because of metatextual suggestions needs a musical explanation - "musical supplement". The objective of the article is the musical and literary dialog, which belongs to intermediality (definition by W. Wolf), and intertextuality in the large sense as well. Although the penetration of musical and literary correspondence does not threaten "scientist hysteria", it also does not promise fruitful strategies and satisfactory conclusions. The paper includes terminological proposals which are an attempt at universal, semiotic transposition into musical and literary borderland, which in the practice of interpretation has too eclectic, and mostly one-time solutions.
\end{abstract}

\section{Semiotyczny dystans}

W badaniach muzyczno-literackich związków korzystanie z ryzykownej, a zarazem często nieodzownej, taktyki interdyscyplinarnej wywołuje obawę „zorganizowania czegoś na kształt sklepu z rozmaitościami” (S.J. Schmidt) ${ }^{1}$. Konieczne jest bowiem uwzględnienie zarówno literaturoznawczej, jak i muzykologicznej perspektywy, czego konsekwencją staje się swoisty eklektyzm warsztatu badawczego ${ }^{2}$. Modelowy odbiorca utworów pogranicznych przyjmuje zatem strategię lekturową, która wymaga korelacji literackich i muzycznych doświadczeń. Przedstawione w artykule założenia teoretyczne koncentrują się na propozycjach terminologicz-

1 Porównaniem tym posłużył się S.J. Schmidt, mówiąc o wyzwaniach, zagrożeniach i koniecznościach literaturoznawstwa uwikłanego w interdyscyplinarność. Zob. S.J. Schmidt, Literaturoznawstwo jako projekt interdyscyplinarności, przeł. B. Balicki, „Teksty Drugie” 2010, nr 4, s. 156.

2 Do podobnych wniosków dochodzi A. Seweryn, która pisze o potrzebie uwzględnienia dwóch perspektyw w badaniach muzykologicznych, „co wiąże się z badawczym eklektyzmem ciążącym nad studiami poświęconymi "gatunkom pogranicza sztuk»” oraz „Postuluje się tym samym odejście od dążeń do czystości metodologicznej na rzecz stosowania adekwatnych do problemu narzędzi badawczych, co bliskie jest także przedstawicielom komparatystyki interdyscyplinarnej”. A. Seweryn, Poezja „nutami niesiona”. O muzycznej recepcji twórczości Juliusza Słowackiego, Warszawa 2008, s. 67 i s. 88. 
nych, które porządkują przebieg analityczno-interpretacyjny w muzyczno-literackich rozpoznaniach.

Wprowadzanie muzyki w przestrzeń słowa ma ograniczony zakres, który słusznie budzi wiele kontrowersji. Z jednej strony są one konsekwencją występowania pustych miejsc $\mathrm{w}$ teorii literatury, między innymi za sprawą niedookreślenia strategii badawczych oraz braku terminologicznej precyzji. Z drugiej - wynikają z samej istoty zjawiska, korespondencja muzyki i literatury jest bowiem trudno uchwytna przede wszystkim ze względu na konfrontowanie odmiennych systemów znakowych ${ }^{3}$. Mimo że „logika muzyczna i muzyczna wyrazowość składają się na jedną warstwę znaczeniową" 4 - różną od semantyki w ścisłym sensie, niemniej obecną - to instrumentarium obsługujące pogranicze muzyka - literatura jest pojęciowo uboższe, choćby o (funkcjonujące od dawna w związkach literatury i sztuk wizualnych) terminy ekfraza i przekład intersemiotyczny.

W rozpatrywaniu filiacji literacko-muzycznych równie ważna jest świadomość obecności barier oddzielających odległe semiotycznie teksty kultury, jak i pamięć o wywodzącej się z antyku syntezie sztuk. Teoretyczne uwagi na temat dialogu słów i dźwięków rozpocznijmy od przywołania myśli prekursora, a zarazem jednego z ważniejszych badaczy muzyczno-literackich związków Calvina S. Browna, który często podkreślał znaczenie wspólnego kulturowego źródła:

W najbardziej pierwotnym stadium społeczeństwa muzyka, literatura i taniec nie były postrzegane jako osobne dziedziny artystyczne, ale jako jedna sztuka. Znacznie później nastąpiło oddzielenie muzyki od literatury. Taniec natomiast nawet współcześnie, mimo że jest osobną sztuką, pozostaje związany z muzyką. Odseparowanie muzyki od literatury nie przebiegało bez wahań, było raz słabszą, innym razem silniejszą tendencją kulturową.

${ }^{3} \mathrm{~W}$ sporze o (a)semantyczność muzyki wyraziście wybrzmiewa głos Carla Dahlhausa, który dowodzi tekstowości dzieła muzycznego, a tym samym istotności jego warstwy znaczeń: „Tonalne «znaczenie» jakiegoś akordu jest - nikt temu nie zaprzeczy - czymś z gruntu innym niż pojęciowe «znaczenie» słowa. A jednak ta jawna inność wcale nie musi owocować poczuciem, że ze względu na dwojakie zastosowanie słowa «znaczenie», lepiej unikać go w odniesieniu do muzyki. Posługiwanie się tu słowem «znaczenie» jest całkowicie usprawiedliwione. Usprawiedliwia je analogia strukturalna zachowana pomimo zasadniczej inności, analogia na tyle istotna, by dostąpić utrwalenia przy pomocy terminu obejmującego obydwie dziedziny - przy pomocy słowa «znaczenie». [...] w muzyce możliwe jest wyróżnienie drugiej warstwy - różnej od substratu akustycznego, porównywalnego z językowym brzmieniem słowa - i to warstwy ciągłej, którą w wieku XVIII i XIX tworzyły funkcje tonalne i związki motywiczne, a którą na tyle, na ile nie wyczerpują jej reguły syntaktyczne, niewątpliwie wolno określić jako warstwę «znaczeń»". C. Dahlhaus, Muzyka jako tekst, [w:] tenże, Idea muzyki absolutnej i inne studia, Kraków 1988, s. 258.

4 Tamże, s. 267. 
Bez względu na to, czy sztuki są traktowane łącznie, czy osobno, mają ze sobą wiele wspólnego. Obie sztuki [muzyka i literatura - A.R.] są raczej audialne, a nie wizualne, obie też nie tyle zajmują przestrzeń, ile rozwijają się w czasie. W rzeczywistości istnieje tylko jedna zasadnicza różnica między muzyką i literaturą; w przeciwieństwie do muzyki, dźwięki w literaturze nie mają dowolnego znaczenia, ale mają swój arbitralny sens. To prawda, że muzyka jest zwykle wykonywana głośno, podczas gdy literatura (z wyjątkiem dramatów) jest czytana cicho, nie wynika to jednak z różnic między sztukami, ale po prostu z systemu naszej edukacji [tłum. własne - A.R.] ${ }^{5}$.

Wprawdzie penetracja muzyczno-literackich filiacji nie grozi współczesnemu badaczowi histeria naukowa ${ }^{6}$, ale też nie obiecuje płodnych strategii i satysfakcjonujących wniosków. I choć nikt już nie kwestionuje wzajemnych wpływów muzyki i literatury, to występujący w ich kontekście metodologiczny spór wydaje się kwestią ciągle aktualną.

Interesującą propozycją porządkowania problematyki pogranicza, w tym literacko-muzycznych filiacji, jest - zaproponowana przez Wernera Wolfa - intermedialność ${ }^{7}$, która wpisuje się w horyzont komparatystyki interdyscyplinarnej ${ }^{8}$. Oto definicja sformułowana w artykule Intermediality Revisited. Reflections on Word and Music Relations in the Context of a General Typology of Intermediality:

5 „In the most primitive stages of society, music, literature, and dance are invariably not three separate arts, but a single one. Only in much later stages do music and literature separate, and of course even in the most sophisticated societies, dance remains tied to music. The separation of music and literature has not been a steady trend, but rather an erratic fluctuation.

Whether joined or separate, however, they have a great deal in common. Both are arts of sound rather than sight, and both exist and develop in time rather than space. In fact, there is only one fundamental difference between them: the sounds of literature have arbitrary meanings attached to them, and those of music do not. It is true that music is normally performed and literature (except for the drama) is not, but this does not point to a difference between the arts, but simply to an accident of our education”. C.S. Brown, Literature and Music. A Developing Field of Study, [w:] Word and Music Studies: MusicoPoetics in Perspective Calvin S. Brown in Memoriam, red. J.-L. Cupers, U. Weisstein, Amsterdam 2000, s. 253-254.

6 J. Opalski, O sposobach istnienia utworu muzycznego $w$ dziele literackim, [w:] tenże, Chopin i Szymanowski w literaturze dwudziestolecia międzywojennego, Kraków 1980, s. 7.

${ }^{7}$ Zob. W. Wolf, Intermediality Revisited. Reflections on Word and Music Relations in the Context of a General Typology of Intermediality, [w:] Word and Music Studies, Essays in Honor of Steven Paul Scher and on Cultural Identity and the Musical Stage, red. S.M. Lodato, S. Aspden, W. Bernhart, vol. 4, Amsterdam 2002, s. 13-34.

8 Zob. A. Hejmej, Interdyscyplinarność $i$ badania komparatystyczne, [w:] tenże, Muzyka $w$ literaturze. Perspektywy komparatystyki interdyscyplinarnej, Kraków 2008, s. 81-107. 
W szerszym znaczeniu intermedialność odnosi się do wszelkiego rodzaju przekraczania granic między tradycyjnymi mediami komunikacji. Ten rodzaj transgresji nie ogranicza się jedynie do jednej pracy czy jednego semiotycznego syste$\mathrm{mu}$, ale jest konsekwencją relacji oraz porównań różnych prac czy różnych semiotycznych systemów [tłum. własne - A.R.] ${ }^{9}$.

Intermedialność zdaje się zatem kategorią pojemną, wielowariantową, a zarazem adekwatną do przemian kulturowych zachodzących we współczesnym świecie. Uwzględnia obszerne spektrum, w którym utwór literacki odnosi się do innego systemu (muzycznego, plastycznego) w ogólności, a nie tylko do kolejnego tekstu, dlatego intermedialność „zakłada [...] rozszerzenie pola badawczego w kierunku analizy funkcjonalnej, która ma za zadanie określić rolę i znaczenie hybrydycznych form komunikacji w szeroko rozumianej kulturze"10.

Odczytywanie dzieła w kontekście odmiennej ontologicznie twórczości wiąże się z kolejnym pojęciem, kluczowym, a zarazem bardziej zadomowionym $\mathrm{w}$ teorii literatury niż intermedialność. Mowa o intertekstualności, której precyzyjne zdefiniowanie jest nader trudne, bowiem - jak zauważa Ryszard Nycz - „zarówno indywidualne koncepcje, jak i całe orientacje badawcze, nie wspominając o swoistości poszczególnych dyscyplin badań nad sztuką i kulturą, definiują to pojęcie w sposób istotnie odmienny, z trudem poddający się systematyzującej refleksji"11.

Przyjmując, a zarazem nieznacznie dostosowując do obranego pola teoretycznej penetracji myśl Manfreda Pfistera, można stwierdzić, że „każdy tekst jest reakcją na poprzedzający go tekst”12 również o proweniencjach wskazujących na inną niż literacką dziedzinę sztuki - w tym także muzykę. W tak szeroko pojętym zakresie intertekstualności mieszczą się zjawiska należące do dyskursywnego uniwersum kultury; ich poznanie zmusza do interdyscyplinarnej produktywności metodologicznej, bowiem:

9 „In this broader sense «intermediality» applies to any transgression of boundaries between conventionally distinct media of communication: such transgressions cannot only occur within one work or semiotic complex but also as a consequence of relations or comparisons between different works or semiotic complexes". W. Wolf, Intermediality Revisited..., s. 17.

${ }_{10}$ M. Wasilewska-Chmura, Przestrzeń intermedialna literatury i muzyki. Muzyka jako model $i$ tworzywo $w$ szwedzkiej poezji późnego modernizmu i neoawangardy, Kraków 2011, s. 24.

11 R. Nycz, Poetyka intertekstualna: tradycje i perspektywy, [w:] Krzysztof Penderecki - muzyka ery intertekstualnej. Studia i interpretacje, red. E. Siemdaj, M. Tomaszewski, Kraków 2005, s. 9.

12 M. Pfister, Koncepcje intertekstualności, przeł. M. Łukasiewicz, „Pamiętnik Literacki" 1991 , z. 4, s. 187. 
dla estetyki ponowoczesnej intertekstualność stanowi przede wszystkim przejaw dyskursywnej interferencji w rodzaju, wywodzącej się z tradycji „słowa dwugłosowego” Bachtina, zasady „konstruktywnej parodii” (Głowińskiego) czy „podwójnego kodowania" (Jencks 1987, Hutcheon 1996, Welsch 1998) - zasadniczo nie dającej się zamknąć czy ograniczyć (językiem danej sztuki czy terytorium danej dyscypliny $)^{13}$.

Dzieło ponowoczesne - rozumiane jako „intertekstualny konstrukt”, „efemeryczny splot heteronomicznych właściwości dyskursywnych”, palimpsestowo zapisana karta - nie poddaje się jednoznacznej, spójnej wykładni, zależy natomiast od strategii lektury przebiegającej według praw „poetyki intertekstualnej” (R. Nycz), która wynika z tradycji kulturowej, interdyscyplinarnej, filozoficzno-literackiej14. Tekst literacki, ale i tekst kultury w ogóle, kryje labirynt sensotwórczych wartości, znajduje się na przecięciu tradycji, w zależności od doświadczeń odbiorczych wywołuje skojarzenia, jest przepojony reminiscencjami i siecią znaczeń. Przekonanie, iż pojedynczy utwór ma swoją wewnętrzną dialogiczną strukturęe15, a zarazem stanowi element większej kulturowej mozaiki, prowadzi do wniosku o konieczności interpretacji dzieła z uwzględnieniem bogactwa konfiguracji jego elementów składowych (jak istotę literackości ujmowali formaliści rosyjscy ${ }^{16}$ ).

Gdy podejrzewamy tekst literacki o związek z tekstem muzycznym (lub systemem muzycznym), koncentrujemy się na kilku podstawowych pytaniach, które pojawiają się już na początku analityczno-interpretacyjnych dociekań:

1) skąd zostały zaczerpnięte elementy budujące dialog między sztuką słów i sztuką dźwięków,

2) w jaki sposób są one sfunkcjonalizowane w strukturze dzieła,

3) jaki mają wkład w semantyczne wyposażenie utworu.

Pytania te - powiedzmy od razu - projektują pewien schemat postępowania, który od rozpoznania muzycznej wskazówki, czyli muzycznego interpretanta, prowadzi do muzycznego horyzontu oczekiwań odbiorczych (muzycznego stylu odbioru). W przypadku dzieła, w którym obecne są literacko-muzyczne związki, zidentyfikowanie muzycznego odniesienia nie przypomina badania źródeł w historycznoliterackim rozumieniu, ale od razu wywołuje charakterystyczny dla intertekstualności, a także intermedialności, relacyjny układ, czyli - nieodłączny według Michała Głowińskiego - żywioł międzytekstowej gry.

${ }^{13}$ R. Nycz, Poetyka intertekstualna..., s. 25.

14 Zob. tamże, s. 28.

15 Zob. J. Kristeva, Stowo, dialog, powieść, [w:] Bachtin. Dialog - Język - Literatura, red. E. Czaplejewicz, E. Kasperski, Warszawa 1983.

16 Zob. Formalizm rosyjski, oprac. M.P. Markowski, [w:] Teorie literatury XX w., red. A. Burzyńska, M.P. Markowski, Kraków 2006, s. 120-122. 


\section{Muzyczne interpretanty ${ }^{17}$}

Jeżeli przyjąć, że niereferencyjna, absolutna muzyka wchodzi w korelacje z literaturą, która korzysta z tego samego zespołu leksykalnego, co język użytkowy - wówczas należy uważać, by bezpodstawnie nie przeprowadzać muzyczno-literackich rozpoznań; związki międzytekstowe powinny być zatem wyraźnie uobecnione. Parafrazując myśl Michała Głowińskiego sformułowałabym tezę: dzieło literackie, jeśli ma nawiązywać do muzyki (formy muzycznej), musi posiadać uwagę metatekstową, wprowadzającą na trop muzyki w literaturze ${ }^{18}$.

Intertekstualność w obrębie „muzyki w literaturze” (S.P. Scher) jest zatem faktem - zabiegiem celowym, przeznaczonym dla czytelnika, który podążając tropem odwołań do sztuki dźwięków, odkrywa elementy budowy znaczeniowej interpretowanego tekstu literackiego. Ponieważ obie dziedziny artystyczne dzieli dystans kodów, napięcia muzyczno-literackie należy wyjaśniać wyłącznie wówczas, gdy elementy konstrukcji dzieła literackiego bądź też nominalne, zwerbalizowane w nim wskazówki przejawiają zewnętrzne, w tym przypadku muzyczne, proweniencje.

Przyjmijmy zatem za Michałem Głowińskim, że również w relacjach muzyka - literatura:

odwołanie intertekstualne jest zawsze odwołaniem zamierzonym, a więc wprowadzonym świadomie (choć stopień owego uświadomienia może być różny), adresowanym do czytelnika [....19.

Uaktywnienie dwóch tekstów z różnych porządków semiotycznych wymaga zatem intencjonalnego sygnału intertekstualności, który jest świadomie wprowadzony do utworu literackiego, stając się „strukturalnym elementem tekstu" i różniąc się zarazem od często przypadkowej reminiscencji, która może jedynie świadczyć o zakresie kulturowego rozeznania pisarza. W pełni prawomocnym sposobem nawiązania dialogu literatury z muzyką jest zatem wskazanie interpretanta, który pełni funkcję mediacyjną między odmiennymi systemami znaków; inaczej mówiąc jest wskaźnikiem, który ujawnia i pomaga zrozumieć, jak czynnik

17 Pojęcie muzycznego interpretanta jest inspirowane interpretacjami Adama Dziadka, który pojęcie obrazu jako interpretanta upowszechnił w rozpoznaniach malarsko-literackiego pogranicza. Zob. A. Dziadek, Obraz jako interpretant, [w:] tenże, Obrazy i wiersze, Katowice 2004, s. 109-143.

${ }_{18}$ Por. M. Głowiński, Literackość muzyki - muzyczność literatury, [w:] Muzyka w literaturze. Antologia polskich studiów powojennych, red. A. Hejmej, Kraków 2002, s. 101-121.

19 M. Głowiński, O intertekstualności, [w:] tenże, Intertekstualność, groteska, parabola. Szkice ogólne i interpretacje. Prace wybrane, t. V, red. R. Nycz, Kraków 2000, s. 16. Pierwodruk: M. Głowiński, O intertekstualności, „Pamiętnik Literacki” 1986, z. 4, s. $75-100$. 
muzyczny (intertekst muzyczny) w tekście literackim powinien być rozumiany.

Przypomnijmy, że pochodzenie pojęcia interpretant sięga teorii znaku autorstwa Charlesa Peirce'a, który interpretanta rozumiał dynamicznie i kreatywnie. Według Peirce'a interpretant, będąc „znaczeniem znaku, był [...] jednocześnie kolejnym znakiem lub ciągiem znaków, za pomocą których mogła zostać wyrażona treść” 20 .

Michael Riffaterre z kolei zastosował pojęcie Peirce'a w refleksji nad semiotyką intertekstualną. Badacz zwrócił uwagę, że:

Interpretant, więź między tym, co już z intertekstu zostało powiedziane, a ponownym zapisem, jakim jest tekst, ma więc jako funkcję tworzenie sposobu tego ponownego zapisu i dyktowanie jego reguł odszyfrowywania ${ }^{21}$.

W kręgu badań intertekstualnych znaczenie interpretanta dopełniają kolejne uwagi Michała Głowińskiego:

interpretant to zespół czynników, który określa w danym kontekście stosunek do tekstu przejętego, czy - w terminologii, jaką posługuje się Riffaterre [...] - intertekstu. Element przejęty z jakiegoś tekstu wcześniejszego należy do sfery tego, co „już zostało powiedziane”, ale właśnie to ,już powiedziane” staje się elementem czegoś nowego („dopiero mówionego”) i przybierać może rozmaite postacie. Interpretant to zawarty w tekście wskaźnik, w pewien sposób instruujący, jak ów element należy traktować, wyznaczający perspektywę, z jakiej ma być postrzegany. Sam tekst przejęty nie jest jeszcze w nowym kontekście wyraźnie znaczeniowo wyposażony. O wyposażeniu tym decyduje właśnie interpretant ${ }^{22}$.

Lektura musi zatem przebiegać poprzez muzyczny interpretant, czyli zespół czynników, określających w nowym kontekście stosunek do intertekstu ( $\mathrm{w}$ tym przypadku dzieła muzycznego). Uwzględnienie tekstu pośredniczącego generuje dopiero kompletny sens utworu literackiego ${ }^{23}$.

Intepretant rozumiany jako stopień ujawnienia muzycznego odniesienia programuje - niejednokrotnie interdyscyplinarną - lekturę tekstu, którą nazywam muzycznym stylem odbioru literatury. Intertekstualność

20 A. Burzyńska, M.P. Markowski, Semiotyka, [w:] ciż, Teorie literatury XX wieku. Podręcznik, Kraków 2006, s. 236.

${ }_{21}$ M. Riffaterre, Semiotyka intertekstualna: interpretant, przeł. K. i J. Faliccy, „Pamiętnik Literacki” 1988, z. 1, s. 314.

22 M. Głowiński, O intertekstualności.

${ }^{23}$ Por. uwagę A. Dziadka odnoszącą się do relacji wiersze - obrazy Breughla: „Lektura każdego z cytowanych tekstów musi przebiegać poprzez obraz interpretant, który w szczególny sposób pobudza do szerszej refleksji egzystencjalnej, etycznej, czy też estetycznej. Oznaki metajęzykowe [...] rozbudzają w czytelniku oczekiwania, sprawiają, że jest on nastawiony na recepcję ekfrazy". A. Dziadek, Obraz jako interpretant, s. 125. 
$\mathrm{w}$ aspekcie muzyczno-literackich powiązań staje się - zgodnie $\mathrm{z}$ uwagą Riffaterre'a - swoistym sposobem czytania ${ }^{24}$.

Interpretant pośredniczący między tekstem literackim a intertekstem muzycznym, a zatem łączący dzieła $\mathrm{z}$ różnych porządków semiotycznych, najczęściej ma charakter językowy. Zdarza się jednak, że do tekstu poetyckiego zostaje wprowadzony zapis muzyczny, fragment partytury, który oddaje konfiguracje intertekstualne trudne bądź niemożliwe do wyrażania słowami (przykładem mogą być muzyczne motta w Podróży zimowej Stanisława Barańczaka).

Samo ukształtowanie dźwiękowe tekstu (tzw. muzyczność I w klasyfikacji Hejmeja)25 nie musi mieć ani założeń intertekstualnych, ani interdyscyplinarnych, mieszcząc się zarazem w ramach literackości. Organizacja języka artystycznego uzupełnia jednak intersemiotyczny repertuar chwytów, do których należą m.in. powtórzenie ${ }^{26}$ i rytm.

To, co okazuje się prawdziwem dla poezji, pojawia się jako prawda także w muzyce - pisze Peiper. - Jedną z najbardziej charakterystycznych cech dawnej muzyki były powtórzenia. [...] Powtórzenie motywu w obrębie frazy, powtórzenie frazy w obrębie melodji, a potem jeszcze repetycje różnych części dzieła, daje jej swobodę wobec etapów raz przebytych, prowadzi ją drogą wolną od hamulców symetrycznych, obdarza ją rozmaitością, oddaje ją polirytmii ${ }^{27}$.

Rytmiczno-eufoniczna strona utworu literackiego nabiera intertekstualnego znaczenia, a nawet może być odbierana jako stylizacja z pogranicza sztuk, gdy towarzyszy jej metatekstowa wskazówka. Najdogodniej rozpatrzeć tę kwestię na przykładzie tekstu poetyckiego, który nawiązuje do tańca - formy muzycznej i który formę tę próbuje naśladować przez zastosowanie zestrojów akcentowych. Rytm jest konstytuującym i rozpoznawalnym parametrem tańca; to on przesądza o jego charakterze niezależnie czy mowa o tańcu towarzyskim (użytkowym, do tańczenia), czy stylizowanym (przeznaczonym do słuchania). Tekst poetycki, w którym można zorganizować układ akcentowanych i nieakcentowanych sylab w sposób analogiczny do schematu rytmicznego w formie tanecznej, korzysta z cech transdyscyplinarnych - elementów wspólnych dla wszystkich sztuk. Szukanie „rytmicznego znaku” walca („na trzy”) czy krakowiaka (synkopowość) w układzie rytmicznym wiersza, który bezpośrednio do tego tańca odsyła (np. w tytule), wydaje się wartościowe poznawczo.

24 Zob. M. Głowiński, O intertekstualności, s. 24.

${ }^{25}$ Zob. A. Hejmej, Muzyczność dzieła literackiego, Wrocław 2002, s. 54-59.

${ }^{26} \mathrm{O}$ spotęgowanym znaczeniu i częstotliwości repetycji w muzyce końca XX wieku pisze S. McClary. Zob. S. McClary, Rap, minimalizm i struktury czasowe $w$ muzyce końca XX wieku, przeł. M. Mendyk, [w:] Kultura dźwięku. Teksty o muzyce nowoczesnej, red. Ch. Cox, D. Warner, Gdańsk 2010, s. 365-375.

27 T. Peiper, Rytm nowoczesny, [w:] tenże, Tędy, Warszawa 1930, s. 87. 
Adam Kulawik, powołując się na wersy z Melodii K.I. Gałczyńskiego: „i prosiła, żeby wierszem, żeby walcem / umuzycznić ją, rzewnie znieśmiertelnić”, rozpatruje utwór poetycki jako przykład stylizacji na formę muzyczną walca.

Rytmika tego wiersza - pisze Adam Kulawik - została zorganizowana w taki sposób, że każdy wers posiada trzy mocne akcenty zestrojowe, zatem jest to taki rytm „na trzy”, który znajduje oparcie w wyrazach walcem i umuzycznić sugeruje czytelnikowi muzyczny charakter tekstu ${ }^{28}$.

Rytm - parametr charakterystyczny dla tańca - przestaje być jednak rozpoznawalnym czynnikiem innych form muzycznych. Prześledzenie układów brzmieniowych nie jest zatem wystarczającym argumentem przemawiającym za transpozycją form polifonicznych lub form opartych na różnicy tonacji (przykładem niech będzie dualizm tematyczny w allegrze sonatowym), a zatem czynnikach kompozycyjnych, które nie znajdują swoich ścisłych ekwiwalentów w językowej materii. Rytmizowanie tekstu nie jest jeszcze muzycznością par excellence ${ }^{29}$. „Rytm, inkantacja nie daje wyrazu" (C. Miłosz), dlatego szeroko rozumiana eufonia nie przesądza o intertekstualnych relacjach ani też o muzycznych walorach utworu literackiego.

Po koniecznej dygresji o możliwościach artystyczno-lingwistycznej płaszczyzny utworu literackiego, a rytmie w szczególności, zaakcentujmy stwierdzenie: dialog różnych sztuk uzasadnia mocna sugestia - najczęściej interpretant o metatekstowym charakterze (tytuł, cytat, nazwa formy muzycznej, nazwisko kompozytora), który inicjuje podjęcie muzyczno-literackiej gry. W obręb intertekstualności wchodzi zatem czynnik metatekstowy. Gdy występuje on w roli nominalnego odniesienia do dźwiękowej kompozycji, wówczas dodatkowo uprawomocnia podejrzenia o strukturalne powinowactwa. Spotykamy wówczas ten rodzaj intertekstualności, który w klasyfikacji Genette'a został nazwany architekstualnością - muzyczny interpretant odsyła bowiem zazwyczaj do ogólnych reguł (formy muzycznej), według których został zbudowany muzyczny intertekst. Uwzględnienie współczynnika formalnego wydaje się tym bardziej konieczne, gdy muzyka jest rozumiana przede wszystkim jako sztuka niereferencjalna - innymi słowy: przebieg elementów dźwiękowych w czasie - a nie jako muzyka programowa.

28 A. Kulawik, Stylizacja na formę muzyczna, [w:] tenże, Poetyka. Wstęp do teorii dzieta literackiego, Kraków 1997, s. 142-143.

${ }^{29}$ Zob. J. Dembińska-Pawelec, „Poezja jest sztuka rytmu”. O świadomości rytmu w poezji polskiej XX wieku (Miłosz - Rymkiewicz - Barańczak), Katowice 2010. 
Intertekstualny układ relacji muzyczno-literackich oddaje schemat trójkąta semiotycznego, który przedstawia miejsce interpretanta jako tekstu pośredniczącego między tekstem literackim a muzycznym intertekstem.

Muzyczny interpretant

(np. tytuł dzieła, nazwa formy muzycznej)

Tekst literacki

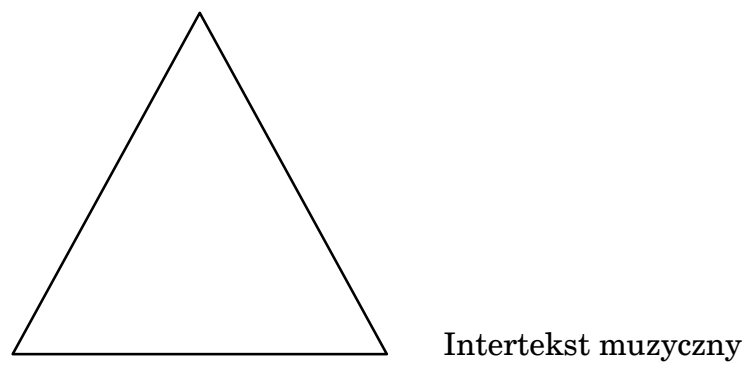

Trójkąt semiotyczny jest na tyle szeroką, interdyscyplinarną formułą, że z powodzeniem wpisuje się w typologię intermedialności. Oprócz konfiguracji muzyka - literatura jest bowiem w stanie obsługiwać innego rodzaju pogranicza, np. z zakresu sztuk wizualnych i muzyki ${ }^{30}$. Według schematu „intermedialności (w szerszym sensie)” Wernera Wolfa $^{31}$ przedstawione relacje należy przyporządkować intermedialności wewnątrzkompozycyjnej. Natomiast w odniesieniu do typów relacji intermedialnych Hansa Lunda ${ }^{32}$, które badacz wydzielił na podstawie zaangażowania mediów, trójkąt intersemiotyczny przedstawia kategorię wzajemnych połączeń.

Za sprawą uwzględnienia muzycznego interpretanta łatwiej zrozumieć „niuanse” znaczeniowe, jak również odkryć pogłębione egzystencjalne, estetyczne czy też etyczne przesłanie tekstu literackiego. Z drugiej strony bez obecności muzycznego interpretanta trudno w ogóle mówić o sensownym doszukiwaniu się literacko-muzycznej palimpsestowości tekstu, jak i stawianiu muzycznych hipotez podczas przeprowadzania interpretacji utworu.

30 Jednym z przykładów może być traktowany jako tekst cykl malarski Dudy-Gracza „obrazujący” dzieła Chopina (intertekst), ale także efekt odwrotnych inspiracji, m.in. cykl fortepianowy Goyescas Enrica Granadosa inspirowany obrazami Francisca Goi.

31 W. Wolf, Intermediality Revisited. Reflections on Word and Music Relations in the Context of a General Typology of Intermediality, [w:] Word and Music Studies: Defining the Field, red. W. Bernhart, S.P. Scher, W. Wolf, Amsterdam-Atlanta 1999, s. 37-58.

32 Zob. M. Wasilewska-Chmura, Medium i intermedialność - definicje, klasyfikacje, perspektywy, [w:] taż, Przestrzeń intermedialna literatury i muzyki..., s. 34-36. 


\section{Muzyczny styl odbioru}

Znalezienie jednoznacznej wskazówki, która zostaje identyfikowana jako muzyczny znak, wywołuje nawykowe postępowanie oraz działania związane z percepcją dzieła muzycznego, a w konsekwencji przełożenie przyzwyczajeń muzycznych na literaturę, co z kolei owocuje percepcją określaną jako muzyczny styl odbioru. Muzyka staje się tym samym jedną ze strategii lekturowych, konotowaną przez samo dzieło literackie i podjętą w interpretacji intertekstualnej (a niejednokrotnie także interdyscyplinarnej oraz intermedialnej). Muzyczny styl odbioru zakłada bowiem lekture przebiegającą tradycyjnym linearnym trybem, a zarazem trybem równoległym, który jest efektem obecności muzycznych intertekstów ewokowanych przez sam tekst i przywołanych w pamięci czytelnika.

Muzyczny styl odbioru charakteryzuje zatem czytelnika-melomana, który rozpoznaje pozaliterackie nawiązania, identyfikuje kulturowe korelacje, wsłuchuje się w ukształtowanie językowe i słyszy jego wewnętrzną brzmieniową organizację, w końcu uwzględnia - często bardzo finezyjną literacką stylizację na formę muzyczną. Strategia słuchania i interpretowania literatury jest propozycją lekturową, która wymaga dokonywania procesu konkretyzacji dzieła muzycznego wskazanego w tekście, a także identyfikowania muzycznych (także formalnych) implikacji.

Odwołania intertekstualne - szczególnie gdy pochodzą z pogranicza sztuk - wymagają orientacji w tekstach kultury, nie ułatwiając procesu rozumienia dzieła. Gra intertekstualna zakłada określone kompetencje odbiorcze, które pomogą skorelować wpływy muzyczne i literackie.

Nie wystarcza bowiem umiejętność postępowania $\mathrm{z}$ danym typem tekstu, zatem znajomość reguł, według których został on zbudowany. W obręb owej kompetencji wchodzi także to, co w innych sytuacjach może być nieważne, a mianowicie znajomość konkretnych utworów, które stały się partnerami intertekstualnej gry, lub też - w pewnych okolicznościach - zdolność określenia typu tekstu.

[...] wzmożona potencjalność relacji intertekstualnych sprawia, że mają one jakby charakter ruchomy, że mogą niekiedy w danym typie odbioru wysuwać się na pierwszy plan tekstu, przy innym zaś sposobie lektury [...] - jakby zanikać (choć oczywiście nadal w tekście istnieją) [...] czytelnik musi się zorientować nie tylko w tym, że żywioł intertekstualny w tekście występuje i określić jego sferę odniesienia, musi także zrekonstruować to, co Riffaterre nazwał interpretantem, przeto swoistą ramę, w którą przywołany element został ujęty ${ }^{33}$.

${ }_{33}$ M. Głowiński, O intertekstualności, s. 26-27. 
„Potencjalność relacji intertekstualnych” była wytłumaczeniem dla odsuwania muzycznych interpretantów na dalszy plan, co pozwalało na interpretacje wykluczające albo traktujące pobieżnie muzyczne interteksty. Rekonstruowanie odmiennego systemowo aspektu estetycznego nie jest jednak aktywnością dowolną, ale stanowi konsekwencję immanentnych właściwości utworu literackiego, który od procesu percepcji oczekuje muzycznych dopowiedzeń - muzycznych dookreśleń. W interpretacji kierowanej muzycznym stylem odbioru spotykają się tym samym dwie równorzędne tradycje kulturowe - literacka i muzyczna.

Przewartościowanie strategii lekturowej wynika poniekąd z uznania sposobności częściowej transpozycji formy muzycznej na literaturę. Napięcia w procesie odbioru są więc ewokowane przez czynniki niejednorodne systemowo (wykraczające poza jeden kod znaków). Styl odbioru, oprócz zwyczajowych literackich cech, nabiera także charakteru percepcji muzyki. Michał Głowiński, formułując przypuszczenie: „właściwości stylu odbioru dają się ująć w kategoriach prawdopodobieństwa”" ${ }^{34}$, powołuje się na audialne doświadczenie dzieła muzycznego. Klasycznie rozumiana forma muzyczna jest bowiem kształtowana według ścisłych zasad systemu dur-moll, w którym układy akordów (następstwa funkcji) konotują zapisaną w nauce harmonii - wymaganą, niejako antycypowaną przez słuchacza, odpowiedź.

Zdarza się, że muzyczną strategię odbioru wyznacza nie tylko poetyka immanentna, ale także metajęzykowe wypowiedzi pisarzy. Jako przykład można podać powszechnie znane komentarze Jarosława Iwaszkiewicza, ale także - równie znamienne - uwagi Barańczaka, który określając proces literackiej twórczości, a zarazem modelowego czytelnika, wyjaśnia:

napięcia, które same dążą w stronę jakiegoś rozwiązania, jak w muzyce d-f-g-h same jak gdyby dążą do rozwiązania się w c-e-g-c - stanowią mechanizm napędowy całej mojej twórczości ${ }^{35}$.

Muzyczno-literackie credo Barańczaka to zarazem gest wpisania sztuki słowa w muzykę, a dokładniej w zasady jej klasycznej harmonii, w której po dominancie (d-f-g-h) zawsze musi nastąpić tonika (c-e-g-c). Poeta nie wybiera zatem nowoczesnej dodekafonii, ale opiera swój literacki system na założeniach systemu dur-moll. Rozszyfrowanie intencji autorskiej wyrażone w zacytowanych słowach wymaga zatem tego rodza-

${ }^{34}$ M. Głowiński, Odbiór, koncepcja, styl, [w:] tenże, Style odbioru. Szkice o komunikacji literackiej, Kraków 1977, s. 55.

35 „Poezja musi być wieczna czujnościa” (ze S. Barańczakiem rozmawiał P. Wierzchowski), [w:] S. Barańczak, Zaufać nieufności. Osiem rozmów o sensie poezji 1990-1992, red. K. Biedrzycki, Kraków 1993, s. 59. 
ju erudycji, która jest efektem osłuchania oraz opanowania kompetencji odbiorczych wystarczających do rozpoznania podstawowych niereferencjalych układów muzycznych. Muzyczny styl odbioru literatury zostaje uzupełniony o przyzwyczajenia ukształtowane przez klasyczny repertuar, który postępuje według znanego odbiorcy klucza, zgodnego $\mathrm{z}$ harmonicznym następstwem funkcji. Warto podkreślić, że oczekiwania czytelnika-słuchacza są często niespełnione, dlatego zamiast podkreślać zbieżności sztuk, eksponują nieprzystawalność składników obsługujących odmienne dziedziny artystyczne ${ }^{36}$. Natomiast w odniesieniu do muzyki współczesnej (od początku XX wieku), kiedy nastąpiło usamodzielnienie wszystkich dźwięków skali, zatem i swobodne posługiwanie się 12 równouprawnionymi tonami, trudno mówić o jakichkolwiek odbiorczych oczekiwaniach i przyzwyczajeniach.

Mimo że eteryczność wywołana temporalnym charakterem utworów dźwiękowych wydaje się powszechnym doświadczeniem, to muzyczne zadania dla czytelnika wznoszą się ponad manifestację jednostkowych przeżyć, wręcz przeciwnie - są efektem wyboru czynników zaprojektowanych i zorganizowanych na różnych poziomach tekstu. Kategoria muzycznego interpretanta, którą traktujemy jako immanentny element relacji intertekstualnych, wyznacza sposób czytania, lekturę niejednokrotnie rekonstruującą na nowych zasadach dzieło muzyczne (formę muzyczną) w ujęciu literackim.

\section{Literacka forma muzyczna}

Interpretacje kierowane muzycznym stylem odbioru zakładają istnienie w literaturze cech dystynktywnych dla form muzycznych, które są rozpatrywane w tekstach obierających za swój genotyp model ukształtowany w pokrewnej dziedzinie artystycznej. Na płaszczyźnie kompozycji reguły muzyczne są porównywalne z zasadami literackimi, dzięki czemu istnieje sposobność dostosowania i zbliżenia medium językowego do dzieła muzycznego. Biorąc pod uwagę obecny stan badań, nikt bodaj nie postawiłby nawet „roboczej tezy”: dzieła literackie mogą być zapisane $\mathrm{w}$ postaci form muzycznych. Ciaggle jednak zasadne wydaje się pytanie kluczowe dla rozprawy Lecha Kolagi - w jakim stopniu forma muzyczna jest realizowana $\mathrm{w}$ tekście literackim ${ }^{37}$. Z przeprowadzonych $\mathrm{w}$ pracy Musikalische Formen und Strukturen in der Deutschsprachigen Literatur

36 Zob. A. Reimann, „Z okna na którymś piętrze ta aria Mozarta”-wiersz z muzycznym akcentem, „Pamiętnik Literacki” 2011, z. 3, s. 114.

${ }^{37}$ L. Kolago, Musikalische Formen und Strukturen in der Deutschsprachigen Literatur des 20. Jahrhunderts, Warszawa 1994, s. 7. 
des 20. Jahrhunderts analiz tekstów literackich Kolago wyciąga następujące wnioski:

przejęcie przez literaturę określonych struktur muzycznych oraz technik kompozytorskich jest możliwe na poziomie poszczególnych elementów dzieła. Całkowita adaptacja form muzycznych na literaturę jest natomiast nie do zrealizowania ze względu na typowe dla muzyki parametry, do których zalicza się: polifonia, modulacja (zmiana tonacji), kontrapunkt, a także z powodu innych cech konstytuujących sztukę dźwięków. Sposobność przejęcia formy muzycznej w literaturze jest możliwa, gdy podniesiemy ją na poziom abstrakcji i z tej perspektywy będziemy rozpatrywać jej znaczenie. Innymi słowy, formę pojmujemy wówczas jako proces kształtowania (formowania) [tłum. własne - A.R.] ${ }^{38}$.

Kolago jednoznacznie konstatuje, że w literaturze forma muzyczna nigdy nie zaistnieje $\mathrm{w}$ taki sam sposób, w jaki funkcjonuje $\mathrm{w}$ sztuce dźwięków. Wartościowe (a wręcz potrzebne) jest zarazem rozpatrywanie zakresu, w jakim muzyka (w tym forma muzyczna) kształtuje dzieło literackie oraz dyktuje jego lekturę, kreując, wzbogacając i wzmacniając nośność znaczeń.

Możliwość transpozycji formy muzycznej budziła zawsze polemiki. Strukturalne filiacje literacko-muzyczne to bowiem ciągle terra incognita, teren niepewnych penetracji naukowych, pozostawiony bez odpowiednich narzędzi badawczych i z rzadkimi punktami orientacyjnymi. Prezentacje muzyki w literaturze - szczególnie w ich wersjach kompozycyjnych - bywają zatem traktowane nieufnie - a czasami wręcz wykluczane - jako model zbyt abstrakcyjny i trudny do zanalizowania. Paradoksalnie jednak to zespół czynników formotwórczych, będący bliski strategiom kompozycyjnym wspólnym dla wszystkich sztuk, wznosi się ponad ograniczenia tworzywa i w sposób niekwestionowalny łączy obie dziedziny; udaje się tym samym obiektywnie porównać reprezentacje form bez popadania $\mathrm{w}$ egzaltowaną (i napiętnowaną przez T. Szulca) manierę. Koligacje konstrukcyjne stają się zatem strategią, w której znajdujemy najwięcej dosłownych, a nie umownych, podobieństw między praktyką pisarską

38 Tamże, s. 339. „Aus der oben durchgeführten Analyse literarischer Werke, in denen musikalische Strukturen nachzuweisen sind und die in Musikformen verfaßt wurden, läßt sich zu der von uns in der Einleitung aufgestellten These folgendes sagen: Die übernahme spezifischer musikalischer Strukturen, Kompositionstechniken und prinzipien in die Literatur ist möglich auf der Ebene einzelner Gestaltungselemente. Dagegen ist eine totale übernahme von Musikformen in die Literatur auf dieser Ebene nicht möglich. Dem stehen im Wege typisch musikalische Parameter wie: Polyphonie, Modulation, Kontrapunktik, der statische Charakter der Themen, änderungen der Tonart. Und dennoch ist die totale übertragung von Musikformen in die Literatur möglich, wenn man die Form auf die Ebene der Abstraktion hebt und sie von dieser Ebene her betrachtet. d. h. wenn man Form als Prozeß der Formung begreift". 
a kompozytorską. Poznanie dzieła literackiego jest wówczas zbieżne $\mathrm{z}$ wdrażaniem się w tajniki muzyki, bowiem - jak zauważa Krzysztof Lipka:

to wszystko, co w dziele muzycznym analizujemy, leży tylko i wyłącznie po stronie formy, zaś wszelkie próby analizowania treści, jakkolwiek nazywanej (istota, sens, idee, emocje etc.), nigdy nie wyszły poza ogólniki ${ }^{39}$.

Dwie podstawowe definicje z zakresu muzykologii wystarczą, by filiacje literacko-muzyczne wpisywać w konteksty pograniczne, uzasadniając zarazem konstrukcyjne zestawienia obu sztuk. Pierwsza pochodzi z podręcznika Józefa Chomińskiego Formy muzyczne:

Określenie „forma muzyczna” oznacza w języku potocznym budowę dzieła muzycznego. [...] Żeby głębiej poznać istotę formy muzycznej, trzeba wziąć pod uwagę fakt, że muzyka jest zjawiskiem rozciągłym w czasie, że w budowie działają różne współczynniki ${ }^{40}$ oraz że utwór muzyczny, podobnie jak i inne wytwory sztuki, posiada treść, którą twórca chciał wyrazić. [...] W ten sposób forma staje się przebiegiem [układów dźwiękowych w czasie - A.R.] ${ }^{41}$.

Chomiński zwraca uwagę na fakt, iż muzyka - podobnie jak literatura - to sztuka temporalna, rozwijająca się w czasie. Zofia Lissa podaje nieco odmienną definicję, podkreślając w niej znaczenie tworzywa, które z kolei przesądza o specyfice dzieła:

forma dzieła muzycznego - to zespół środków, które nadają treści określony konkretny kształt. W każdym gatunku sztuki elementy i zasady kształtowania formy są odmienne, wynikające z tego, co jest surowcem, materiałem danej sztuki ${ }^{42}$.

Forma muzyczna w obrębie słów zawsze jest przekształcana, znajduje swoje indywidualne, osobne realizacje, dlatego różni się od rozumienia muzykologicznego. Tekst, w który wpisuje się struktura obca, potęguje wieloznaczność wypowiedzi językowej. Dopiero rozpoznanie sensotwórczych relacji między elementami utworu pozwala uwzględniać interpretacyjne warianty. Przyjęte w metodologii intertekstualne znaczenie formy muzycznej sytuuje się między jej zleksykalizowanym muzykologicznym rozumieniem a formą tłumaczoną jako kompozycja, czyli kon-

${ }^{39}$ K. Lipka, Warstwowy układ treści dzieła muzycznego, [w:] Filozofia muzyki. Studia, red. K. Guczalski, Kraków 2003, s. 161.

40 Należą do nich: melodyka, harmonika, rytmika, agogika, dynamika i kolorystyka. Zob. J.M. Chomiński, Elementy muzyczne, [w:] tenże, Formy muzyczne, t. I, Kraków 1954, s. 11-60.

41 Tamże, s. 9.

42 Z. Lissa, Podstawy estetyki muzycznej, t. I, Warszawa 1953, s. 10. 
strukcja dzieła. Forma muzyczna ${ }^{43} \mathrm{w}$ takim ujęciu często zbliża się do chwytu literackiego (by użyć terminu Wiktora Szkłowskiego).

Skoncentrowanie się na formie muzycznej jako wyjściowym czynniku badań literacko-muzycznych związków jest, z jednej strony, konsekwencją muzycznego stylu odbioru literatury, z drugiej - wynika z przeświadczenia o podobieństwie i pokrewieństwie morfologii tekstów, należących do różnych systemów znakowych. Odpowiednikiem formy muzycznej w literaturze jest gatunek, którego definicja - sformułowana przez Balcerzana $\mathrm{w}$ artykule zatytułowanym $W$ strone genologii multimedialnej okazuje się adekwatna także do innych niż literackie przejawów inwencji artystycznej człowieka ${ }^{44}$ :

Czym jest gatunek? Jest powtarzalną kombinacją chwytów - decydujących o kompozycji (morfologii) tekstu, komunikacyjnie ukierunkowanych i zdeterminowanych przez materiał oraz technikę przekazu (medium) ${ }^{45}$.

Najprostszym sygnałem więzi między gatunkami z odmiennych systemów komunikacyjnych są zapożyczenia terminologiczne, obecne najczęściej w tytule dzieła (przykładem są poetyckie nokturny i fugi, z kolei w muzyce m.in. poematy symfoniczne, pieśni bez słów). Postawmy jednak pytania, które z podobieństw konstrukcji łączą formę muzyczną z tekstem literackim, a które pozostaną jedynie iluzją bądź mrzonką identyczności. Badając teksty literackie powołujące się na formę muzyczną, należałoby zatem rozpatrzeć „kombinację chwytów”, które wyzwoliłyby kategorialną istotę pojedynczego zjawiska, czyli muzyczny fenotyp, świadczący o tym, że tekst literacki wybrał za wzór gatunek pokrewnej sztuki.

Refleksja nad pojedynczymi analogiami schematów kompozycji tekstowych, a także porównanie zaprzyjaźnionych porządków komunikacyjnych („literatura a muzyka”, „wypowiedź literacka a wypowiedź filozoficzna”) wspierają dążenie do wiedzy integrującej owe próby ${ }^{46}$.

Ukierunkowanie na poszukiwania uniwersalnych reguł rządzących gatunkami w różnych tekstach kultury prowadzi do ujęcia całościowego, które można ogólnie nazwać genologia kultury (E. Balcerzan). Za tego

${ }^{43}$ Za J.M. Chomińskim można przyjąć definicję: „Forma muzyczna jest wypadkową współdziałania elementów muzycznych, jako środek służący do realizacji pozamuzycznej treści dzieła, to utwór realizowany za pomocą zasobów środków techniki kompozytorskiej, nierozerwalnie związany z danym środkiem wykonawczym i typową dla niego fakturą". Definicję podaję za D. Wójcik, ABC form muzycznych, Kraków 2003, s. 13.

44 Według E. Balcerzana kompozycja - kluczowa dla definicji gatunku - jest czynnikiem łączącym zarówno symfonię, koncert, sonet, jak i podręczniki, konferencje prasowe czy nabożeństwo. E. Balcerzan, W strone genologii multimedialnej, [w:] Genologia dzisiaj, red. W. Bolecki, I. Opacki, Warszawa 2000, s. 88.

45 Tamże.

46 Tamże, s. 87. 
rodzaju spojrzeniem przemawia przekonanie o pierwotnej wspólnocie sztuk, której pamięć można wskrzesić, podejmując semiotyczną grę z barierami gatunkowymi.

Utwór literacki, który na zasadzie relacji intertekstualnej, sięga po formę muzyczną, eksponuje poziom nawiązań architekstualnych, poszerzając $\mathrm{w}$ ten sposób pole odniesień genologicznych o pokrewną dziedzinę artystyczną. Czy jednak w genologii porównawczej, która jest możliwa w praktykach czytelniczych, należy dopatrywać się generalnych procesów $\mathrm{w}$ obrębie literatury, które wiążą się z zacieraniem granic już nie tylko między tradycyjnymi gatunkami, ale między formami literackimi a nieliterackimi ${ }^{47}$ ?

W relacjach muzyczno-literackich manifestacja „światopoglądu formy" nie tyle prowadzi do systemowych uogólnień, ile raczej do dobrze znanego przekonania, iż jednostkowy utwór literacki realizuje kody artystycznych tradycji, zarazem w procesie lektury ucząc swojego jedynego niepowtarzalnego kodu (J. Łotman). W odniesieniu do opartej na empirii sztuki interpretacji, która śledząc formy muzyczne w tekście literackim często musi powoływać „wiele jednorazowych poetyk”, sentencja Derridy: „Nie ma nic prócz tekstów”, wybrzmiewa nader mocno.

$$
* * *
$$

„Dzięki muzyce lepiej rozumiem Tekst jako signifiance” - napisał Roland Barthes w swoich pismach poświęconych sztuce dźwięków ${ }^{48}$. W muzyce zwanej absolutną forma staje się „nośnikiem znaczen” - przyjęcie tego założenia pozwala wybrnać $\mathrm{z}$ pasm niepowodzeń, które są konsekwencją zazwyczaj chybionych literackich opisów sztuki dźwięków. Próby transponowania konstrukcji muzycznej do utworu literackiego mają kilka celów - z jednej strony porządkują (czy też starają się porządkować) kompozycję literacką na zasadach struktur muzycznych, z drugiej natomiast wpływają na sferę semantyczną (fabularną). Forma muzyczna staje się czynnikiem kompozycyjnym i sensotwórczym jednocześnie. Nie występuje więc dychotomiczny, nienaturalny podział na plan treści i plan wyrażania, nie można bowiem rozumieć treści inaczej jak poprzez formę i odwrotnie - dopiero wzajemne napięcia kształtują całościowy obraz utworu i odkrywają nowy potencjał znaczeń.

Do odmiennych wniosków doszedł badacz hermeneutyki muzycznej Hermann Kretzschmar, który główny sens muzyki widział nie w formie

${ }^{47}$ Por. S. Balbus, Zagłada gatunków, [w:] Genologia dzisiaj, s. 21.

${ }^{48}$ Cyt. za K. Kłosiński, Signifiance. Wstęp do pism Rolanda Barthes’a o muzyce, „Pamiętnik Literacki” 1999, z. 2, s. 11. 
jako autonomicznej, absolutnej konstrukcji, lecz w afektywnej treści muzyki. Pisze on, iż muzyka:

daje obrazy istoty życia wewnętrznego o bogactwie i subtelności, które są możliwe tylko dla niej49.

Rozpoznawanie filiacji literacko-muzycznych nie może opierać się na jej zdolności wpływania na odczucia odbiorcy, których badanie wymyka się miarodajnym kategoriom. Poddająca się naukowemu ujęciu konstrukcja dźwiękowa zostaje tym samym zastąpiona ciągiem afektów, a nie spójną i poznawalną strukturą. Do myśli hermeneutycznej krytycznie ustosunkowuje się Maria Piotrowska, twierdząc, że mamy do czynienia $\mathrm{z}$ „żenująco płytką”, często addycyjną koncepcją dzieła muzycznego ${ }^{50}$. Słowa Piotrowskiej potwierdzają, że badania interdyscyplinarne ciągle wywołują metodologiczną burzę i zmagają się z niedoprecyzowanym instrumentarium, które często staje się każdorazowym szukaniem adekwatnych rozwiązań.

W rozumieniu muzykologów pojęcie forma muzyczna oznacza ustalony, skodyfikowany schemat utworu dźwiękowego, w którego ramach dopuszcza się niewielkie odstępstwa od przyjętych zasad kompozycyjnych, a więc pewną dowolność interpretacji. Sytuację osobliwą obserwujemy w muzyce współczesnej, która niegdyś obowiązujące zasady celowo zakłóca, często pozostawiając jednak tradycyjną nazwę przekornie lub z powodu braku bardziej trafnych terminów. Dla klarowności teoretycznych założeń warto podkreślić, że punktem odniesienia nie jest forma muzyczna w jej wariancie osobnym, czyli indywidualnej realizacji, ale w postaci skodyfikowanej, modelowej. Istotne okazuje się zatem nie tylko szukanie ekwiwalentów muzycznych w literaturze, ale także zagadnienie formy muzycznej jako genotypu utworu, a więc typowego schematu, rozpoznawalnego za pomoca czynności analitycznych. Podejmowane zagadnienia form (technik muzycznych) niejednokrotnie już wcześniej znalazły swoje zastosowanie $\mathrm{w}$ teorii literatury; wspomnijmy choćby o polifonicznym rozumieniu powieści wprowadzonym przez M. Bachtina ${ }^{51}$ czy kwestii literackich fug 52 .

49 Cyt. za L. Polony, Pojęcie znaku i symbolu w muzyce w myśli klasyków hermeneutyki muzycznej: Kretzschmara i Scheringa, [w:] Filozofia muzyki. Studia, red. K. Guczalski, Kraków 2003, s. 173.

50 Zob. M. Piotrowska, Tezy o możliwości hermeneutyki muzycznej w świetle stu lat jej historii, Warszawa 1990, s. 190 oraz L. Polony, Pojęcie znaku i symbolu..., s. 175.

51 Zob. M. Bachtin, Estetyka twórczości stownej, przeł. D. Ulicka, oprac. tłum., wstęp E. Czaplejewicz, Warszawa 1986, s. 502.

52 Zob. A. Dziadek, „Fuga” Rafała Wojaczka, [w:] tenże, Obrazy i wiersze, s. 94-107. A. Hejmej, Literackie fugi („Preludio e fughe” U. Saby $i$ „Todesfuge” P. Celana), „Pamiętnik Literacki” 1999, z. 2, s. 96. 


\section{Stylizacyjna obecność formy muzycznej}

Jeżeli muzyczny interpretant odsyła bezpośrednio do formy muzycznej (lub dzieła muzycznego), wówczas odczytanie utworu literackiego polega na śledzeniu form muzycznych sfingowanych w słowach. Do naśladowania konstrukcji muzycznych można odnieść określenie Danuty Danek cytat struktury - w literaturze jest on rozumiany jako typowa i syntetyczna prezentacja specyficznych cech, m.in. stylu, gatunku, poetyki ${ }^{53}$ - co adekwatnie odpowiada relacjom w przestrzeni intertekstualnej. Muzyczność literatury oscyluje bowiem między zagadnieniem interdyscyplinarności a szeroko rozumianą stylizacją.

Stylizacja, która oznacza „naśladowanie języka innego środkami języka własnego" 54 , zajmuje stałe miejsce w repertuarze przejawów intertekstualności55. W sytuacji, gdy w tekście literackim zostaje wprowadzony tytuł będący zarazem nazwą formy muzycznej, mającej więc z założenia autoteliczny charakter, wówczas jedynym czynnikiem łączącym hipertekst $\mathrm{z}$ hipotekstem jest czynnik formalny. Posługując się $\mathrm{w}$ dalszym ciągu terminologią Genette'a, powiedzielibyśmy, że spotykamy wówczas zjawisko wpisujące się w sferę architekstualności, która w przypadku relacji muzyczno-literackich realizuje się zawsze częściowo ze względu na nieprzekładalne parametry sztuk. Śledzimy zatem sprzężenia między regułami formy muzycznej, która - co oczywiste - nie ma charakteru literackiego a próbą jej literackiej adaptacji. Zasady muzyczno-literackiej gry przywołują $\mathrm{w}$ pamięci pojęcie mimetyzmu formalnego, o którym Michał Głowiński pisze, że:

polega [...] na podjęciu reguł wypowiedzi nieliterackiej lub paraliterackiej, na ogół o wyraźnie zaznaczonych cechach i wyraźnym zakotwiczeniu społecznym, przez wypowiedź literacką, dysponującą swoją własną architekstualnością. Mimetyzm formalny nie sprowadza się więc do przejęcia elementów konkretnego utworu, odnosi się do pewnych reguł - i w konsekwencji tworzy swoiste ramy dla relacji intertekstualnych ${ }^{56}$.

W dziele muzycznym, pozbawionym programowych treści, sens jest ewokowany za sprawą układu elementów składowych, dlatego sfera znaczeń nakłada się na sferę kompozycji. W badaniach dialogu sztuk mimetyzm formalny można zatem włączyć do interdyscyplinarnego instrumentarium.

53 Zob. D. Danek, O cytatach struktury (quasi-cytatach), [w:] taż, O polemice literackiej w powieści, Warszawa 1972, s. 70-115.

${ }_{54}$ M. Głowiński, O intertekstualności, s. 9.

55 Zob. hasło stylizacja, [w:] Słownik terminów literackich, red. M. Głowiński, T. Kostkiewiczowa, A. Okopień-Sławińska, J. Sławiński, Wrocław 1998, s. 538-539.

${ }_{56}$ M. Głowiński, O intertekstualności, s. 13. 
Zauważmy, że interpretacja polegająca na przypisywaniu muzyce treści literackich jest nieuzasadniona, dlatego stanowi negatywny sposób myślenia o literacko-muzycznych filiacjach. Nie respektuje bowiem specyfiki sztuki dźwięków, która jedynie okazjonalnie wskazuje na desygnat istniejący w pozaartystycznej rzeczywistości (m.in. przypadek muzycznego naśladownictwa, tzw. imitazione della natura), chętniej podążając ku sztuce absolutnej niż ku prawom życiowym. Poziom konstrukcji otwiera natomiast sferę uniwersalnego myślenia o analogiach między tekstami kultury, ukazując wspólną przestrzeń powinowactwa sztuk. Założenie, iż forma muzyczna jest nośnikiem znaczeń, które mogą wpływać na tekst literacki, proponuje nowy sposób czytania utworów literackich. Muzyczność nie zostaje tym razem zredukowana jedynie do sfery brzmień czy tematu, ale uwzględniana jest na wielu poziomach organizacji tekstu.

Innego rodzaju niż strukturalne próby wdrożenia „asemantycznej” muzyki w ramy literatury, choć sprawa znaczeń w sztuce dźwięków jest kwestią sporną ${ }^{57}$, okazują się zazwyczaj mało wiarygodne. W przeciwieństwie do utworu wokalno-instrumentalnego, w którym akcent muzyczny jest silniejszy od językowego, w tekście literackim brzmienie słów nie dominuje nad konotacjami znaczeniowymi - wyłączam przy tym wiersze o charakterze eksperymentatorskim, które wykorzystują jedynie foniczne walory języka ${ }^{58}$.

To prawda, że kompozycja muzyczna nie zdoła usunąć z utworu jego „zawartości myślowej”, która zatem również wymaga kompozycyjnego ujęcia - pisze Stanisław Dąbrowski. Muzyczny wzorzec kompozycyjny ogarnia składnię, wersyfikację, ale także pisarską „gospodarkę” motywami tematycznymi. Refren, i parafraza; paralelizowanie, kontrastowanie i przeplot motywów, albo ich „uwerturowe” skupienie, albo ich wariacyjne przetwarzanie; naśladowanie schematu fugi, sonaty; ustalenie motywów, „przewodnich” (lejtmotyw) - oto różne przykłady ujmowania motywiki utworu w (zdawałoby się) innorodne dla literatury porządki organizacyjne $[. . .]^{59}$.

Studia nad pograniczem sztuk wymagają niejednokrotnie porównania praktyki kompozytorskiej z pisarską. Kwestia ta jest wyjątkowo waż-

57 Muzyce, choć nie jest ona zaliczana do sztuk przedstawieniowych, trudno odmówić konotowania określonych treści, mimo iż są one mobilne i indywidualnie interpretowane przez odbiorcę. Zob. Z. Lissa, O tak zwanym rozumieniu muzyki, [w:] taż, Nowe szkice z estetyki muzycznej, Kraków 1975.

58 Przykładem może być futurystyczne „branie słowa jako dźwięku” (Szkłowski), co wiąże się z kolei z autonomią artystycznego materiału. Idei tej bliska jest m.in. praktyka poezji dadaistycznej, stosowanie glosolalii, które zamiast semantyki stawiały nacisk na brzmieniową stronę języka.

59 S. Dąbrowski, Muzyka w literaturze, [w:] Muzyka w literaturze. Antologia..., s. 164. 
na, gdy spotykamy stylizację 60 , bowiem „kompozycja «muzyczna» nie może zastąpić w dziele literackim kompozycji literackiej - pisze Stanisław Dąbrowski - może się co najwyżej nad nią stylizacyjnie nadbudować i to - częściowo"61. Między materią słów i dźwięków istnieje różnica surowców, dlatego zbliżenie tekstu literackiego do muzyki odbywa się na zasadzie pars pro toto poprzez szukanie ekwiwalentów - niestety często majaccych charakter nazbyt umowny. W literaturze zostają przejęte istotne - ale nie wszystkie! - właściwości innego stylu62. Kompozycyjna stylizacja staje się szczególną artystyczną metodą (re)interpretacji muzyki $\mathrm{w}$ literaturze.

Ponieważ adaptacja struktury muzycznej na sztukę słowa ma zawsze charakter niepełny, prawidłowo byłoby wprowadzić pojęcie rekompozycji muzycznej ${ }^{63} \mathrm{w}$ literaturze, dla podkreślenia osobności i jednorazowości zabiegu artystycznego, oraz reinterpretacji - dla scharakteryzowania metody analizy i interpretacji, które wymagają doboru adekwatnego, często nowego instrumentarium. Trafne jest także - wspomniane wcześniej - stosowanie mimetyzmu formalnego, który Michał Głowiński64 zaproponował na określenie rodzaju stylizacji $\mathrm{z}$ typowym dla niej przeniesieniem reguł kompozycyjnych, stosowaniem wspólnych cech formalnych, a w końcu prób adaptacji obcej konstrukcji.

Muzyka i literatura wydają się od siebie bardzo odległe. Dźwięki, niemające mocy przedstawieniowej, wykluczają możliwość opisu, który z kolei jest domeną słów. Materia językowa natomiast prezentuje ubogi zakres fonicznych możliwości, które - dodajmy - nigdy nie dostarczą wrażeń estetycznych równych kompozycji muzycznej. Opozycje wynikające ze specyfiki obu mediów ulegają zwielokrotnionej komplikacji strukturalno-znaczeniowej. Wchodzą $\mathrm{w}$ interakcje wzmagające wyrazistość i wzbogacające wypowiedź literacką. Tworzą znaczące opozycje między elementami wywołującymi artystyczną ekspresję. Stylizacja na formę muzyczną byłaby zatem zaktywizowaniem jej w tworzywie innej sztuki, w tym przypadku literatury.

${ }^{60}$ Zob. S. Balbus, Zagłada gatunków, s. 19-20, a także T. Kostkiewiczowa, Stylizacja [hasło], [w:] Słownik terminów literackich, red. J. Sławiński, Wrocław 1988.

61 S. Dąbrowski, Muzyka w literaturze, [w:] Muzyka w literaturze. Antologia..., s. 163.

62 A. Hejmej wprost stwierdza: „nie istnieje żadna adekwatna przekładalność dzieła muzycznego na dzieło literackie, co oznacza w szerszej perspektywie, przez prostą analogię, niemożliwość wzajemnego transponowania sztuk". A. Hejmej, Literackie fugi..., s. 95.

63 Pojęcia tego po raz pierwszy użył Stanisław Dąbrowski w art. Muzyka w literaturze, s. 165.

${ }^{64}$ Zob. M. Głowiński, O powieści w pierwszej osobie, [w:] tenże, Gry powieściowe. Szkice $z$ teorii $i$ historii form narracyjnych, Warszawa 1973, s. 63-65. 


\section{Pytanie o przyczynę...}

Tekst słowny, adaptując (dodajmy - zawsze częściowo) formę muzyczną, zapośrednicza cechy samozwrotności i niereferencjalności sztuki dźwięków. Literatura w różnych wariantach artystycznych ciągle zmaga się bowiem z wpisanymi w nią ograniczeniami:

właściwe wszystkim sztukom - pisze Ewa Wiegandt - dążenie do przekraczania własnych granic, a w wypadku literatury jest ono najskuteczniejsze, gdy upodobnienie do sztuk innych odbywa się na płaszczyźnie pozawerbalnej. Jest nią bezsprzecznie kompozycja ${ }^{65}$.

Mowa obciążona życiowymi kontekstami od zawsze próbowała zbliżyć się do ideału sztuki absolutnej, której „wcieleniem” była muzyka czysta. Zainteresowanie formami muzycznymi zdaje się wynikać z niewystarczalności tradycyjnego repertuaru gatunków ${ }^{66}$, które są poddawane próbom daleko idących modyfikacji, niejednokrotnie przechodząc w ten sposób w tekstowe hybrydy. Sięganie do zasobów genologicznych z innej dziedziny artystycznej wskazuje na możliwość przeprowadzenia raz bliższych, innym razem dalszych paralel. Mimo że sprawą dyskusyjną są próby przejmowania form muzycznych przez sztukę werbalną - gdzie autoteliczność oraz relacyjny charakter dźwięków przestaje być obowiązującą zasadą - to samo zjawisko zdaje się przekazywać ważną informację o stanie literatury współczesnej, która coraz częściej szuka nowych w tym także muzycznych - wyrazów ekspresji. Nawet jeżeli muzyczne określenia gatunkowe przejęte przez literaturę niewiele mają wspólnego ze swoimi prototypami, niejednokrotnie bowiem okazują się nietrafne, metaforyczne, konwencjonalne... - to nie można wykluczyć - a tym bardziej zakładać - ich bezzasadności; są przecież przejawem intencji umuzycznienia tekstu słownego, a więc także zamiarem wypowiedzenia się za pośrednictwem innego niż tylko literackie medium.

Jeśli proponowany muzyczny styl odbioru ma być kluczem do nośnych interpretacji tekstów literackich, powinny zostać spełnione określone wymagania, które znajdują się zarówno po stronie odbiorcy, jak i po stronie tekstu. Strategię intertekstualną jest w stanie podjąć odbiorca świadomy literacko-estetycznych konotacji utworu. Czytelnik, który zdemaskuje także fakt, iż tekst wywołuje fałszywe muzyczne skojarzenia. $\mathrm{W}$ interpretacji, a właściwie reinterpretacji utworu, spotykają się więc

65 E. Wiegandt, Powinowactwa przez kompozycję w literaturze nowoczesnej, [w:] Intersemiotyczność, red. S. Balbus, A. Hejmej, J. Niedźwiedź, Kraków 2004, s. 376.

${ }_{66} \mathrm{Na}$ zjawisko odwrotne, czyli przenikanie gatunków literackich do muzyki zwrócił uwagę Michał Głowiński. Zob. M. Głowiński, Gatunki literackie w muzyce, [w:] tenże, Narracje literackie i nieliterackie, Kraków 1997, s. 183-188. 
powiązania raz spełnionych, innym znów razem zawiedzionych oczekiwań. By nie zagubić się w proponowanych interpretacyjno-analitycznych rozwiązaniach, należy przyjąć kilka warunków, które uprawomocnią przeprowadzanie intertekstualnych rozpoznań. Zapewne nie dokona się nadinterpretacji utworu ${ }^{67}$, gdy wskazówki w nim zawarte - muzyczne interpretanty - kierują bezpośrednio ku muzycznym korelacjom (muzycznym intertekstom). Sposób rozumienia utworu przez odbiorcę nie może bowiem diametralnie odbiegać od intencji tekstu, innymi słowy nie ma sensu zadawać tekstowi pytań o treści, których on ani nie prowokuje, ani w żaden sposób nie stara się ukryćc8. Wprowadzanie zbędnych - w tym przypadku muzycznych - kontekstów zamiast poszerzyć pole interpretacji, wprowadzi komunikacyjny bałagan. Gdy w centrum zainteresowania znajduje się muzyka w literaturze, wówczas wymagane są nowe interdyscyplinarne zasady czytania, które nie będą skoncentrowane jedynie literaturocentrycznie. Tak ujęta problematyka literacko-muzycznych filiacji wpisuje się $\mathrm{w}$ horyzont komparatystyki interdyscyplinarnej69. Muzyczny styl odbioru kierowany muzycznymi interpretantami jest $\mathrm{z}$ założenia jak najbliższy percepcji muzyki (do początku XX wieku) i zgodny z wyznaczonymi przez nią zwyczajami. Muzyczne oczekiwania względem tekstu nigdy nie będa jednak w pełni spełnione, co z jednej strony akcentuje interdyscyplinarne „inności”, z drugiej otwiera na obszary kulturowe wymagające nowych rozstrzygnięć badawczych.

${ }^{67}$ Czego wielu badaczy subtelnych zależności między literaturą a muzyką nie potrafiło się ustrzec.

68 Tego rodzaju działanie interpretacyjne nie mieści się nawet $\mathrm{w}$ kompromisowym stanowisku przyjętym przez J. Cullera. Zob. J. Culler, W obronie nadinterpretacji, [w:] U. Eco, R. Rothy, Ch. Brooke-Rose, Interpretacja i nadinterpretacja, red. S. Collini, przeł. T. Bieroń, Kraków 1996, s. 113-114.

69 Zob. A. Hejmej, Interdyscyplinarność i badania komparatystyczne, s. 81-107. 
